University for Business and Technology in Kosovo

UBT Knowledge Center

UBT International Conference

2014 UBT International Conference

Nov 8th, 3:45 PM - 4:00 PM

\title{
Transportation management in Kosovo
}

Teuta Kryeziu

University of Prishtina, teuta-kryeziu@hotmail.com

Besjana Kryeziu

Haxhi Zeka University, besjana.kryeziu@hotmail.com

Egzon Kryeziu

Haxhi Zeka University, egzon_kryeziu@hotmail.com

Follow this and additional works at: https://knowledgecenter.ubt-uni.net/conference

Part of the Business Commons

\section{Recommended Citation}

Kryeziu, Teuta; Kryeziu, Besjana; and Kryeziu, Egzon, "Transportation management in Kosovo" (2014). UBT International Conference. 42.

https://knowledgecenter.ubt-uni.net/conference/2014/all-events/42

This Event is brought to you for free and open access by the Publication and Journals at UBT Knowledge Center. It has been accepted for inclusion in UBT International Conference by an authorized administrator of UBT Knowledge Center. For more information, please contact knowledge.center@ubt-uni.net. 


\title{
Transportation management in Kosovo
}

\author{
Teuta Kryeziu ${ }^{1}$, Besjana Kryeziu ${ }^{2}$, Egzon Kryeziu ${ }^{3}$ \\ ${ }^{1}$ University "Hasan Prishtina" Pristina Faculty of Economics Department: Management and \\ Informatics \\ ${ }^{23}$ University "Haxhi Zeka" Department: Business Administration \\ teuta--kryeziu@hotmail.com, besjana.kryeziu@hotmail.com, egzon_kryeziu@ hotmail.com
}

\begin{abstract}
In this paper we are dealing with scientific management of transport in Kosovo The main aim of this research paper is how management made transport in Kosovo, management of roads, railway management, management of air transport.

Kosovo roads categorization: international, regional, as roads are paved and asphalted for the year 2012 - 2013, international road is a public road that, with international act is classified road network of international, highways public road officially categorized as a Main Road, connecting two or more cities and which can serve as links with the neighboring countries, regional Roads public road officially categorized as a regional road, which connects two or more major cities

local roads public road officially categorized as a local road connecting settlements inhabited areas within a municipality, unclassified road means any road that is not a public road, the owner of which is a citizen or group of citizens, and not the Ministry's responsibility, but which is not officially used by pedestrians, vehicles and other moving sideways move in space unmarked, no paved road mean free path and road surfaces built without road coating even to the point of connection with the public road surface build road, rail capacity in Kosovo for the year 2012 - 2013, the number of flights to Kosovo for the year $2012-2013$
\end{abstract}

Keywords: management, transport, road, railway, air.

\section{Introduction}

In this work we have to do with transportation management in Kosovo, Categorization of roads in Kosovo as in those international, regional, and streets of Kosovo by category as we kilometer roads are paved and unpaved for the year 2012 - 2013 International road is a public road that, with international act is classified road network of international, highways public road officially categorized as a Main Road, connecting two or more cities and which can serve as links with the neighboring countries, regional Roads public road officially categorized as a regional road, which connects two or more major cities, local roads public road officially categorized as a local road connecting settlements inhabited areas within a municipality, unclassified road means any road that is not a public road, the owner of which is a citizen or group of citizens, and not the Ministry's responsibility, but which is not officially used by pedestrians, vehicles and other moving sideways move in space unmarked, no paved road mean free path and road surfaces built without road coating even to the point of connection with the public road surface build road

Kosovo railway capacity, the number of passengers in thousands, the amount of goods

Transported in thousands of tons, the amount of freight transported in million tons - km per year from 2012 to 2013.

Number of flights for the year 2012 - 2013 The number of passengers for the year 2012 - 2013, the average number of passengers per flight

\section{Transportation Management in Kosovo}

International road is a public road that, with international act is classified road network of international Highways public road officially categorized as a Main Road, connecting two or more cities and which can serve as links with the neighboring countries . 
Regional Roads public road officially categorized as a regional road, which connects two or more major cities

Local roads public road officially categorized as a local road connecting settlements inhabited areas within a municipality ;

Unclassified road means any road that is not a public road, the owner of which is a citizen or group of citizens, and not the Ministry's responsibility, but which is not officially used by pedestrians , vehicles and other moving sideways move in space unmarked .

No paved road mean free path and road surfaces built without road coating even to the point of connection with the public road surface build road.

\subsection{The roads of Kosovo}

The roads of Kosovo by category, international, regional location of signs for the years 2012 - 2013

In 2012 international road were added to $22.4 \mathrm{~km}$, and $2013 \mathrm{~km}$ of roads were added 20 international and now international road length is $80.4 \mathrm{~km}$.

Highways are paved in for $630.4 \mathrm{~km}$, and 2013 are the same as we raised the previous year 630.4.

Regional roads are paved in for $1294.7 \mathrm{~km}$, and 2013 are hospitalized same as in the previous year 1294.7.

Table.1. The roads of Kosovo by categories.

\begin{tabular}{ccc}
\hline $\begin{array}{l}\text { The roads of } \\
\text { Kosovo by } \\
\text { category }\end{array}$ & & \\
\hline & 2012 & 2013 \\
International & 60.4 & 80.4 \\
Highways & 630.4 & 630.4 \\
Regional & 1294.7 & 1294.7 \\
Total & 1985.5 & 2005.5 \\
\hline \multicolumn{3}{l}{ Sources: Department of Kosovo roads }
\end{tabular}

According to data presented by the year 2012 in the territory where we $1985.5 \mathrm{~km}$ international road highways are $3 \% 32 \%$ while $65 \%$ are regional roads

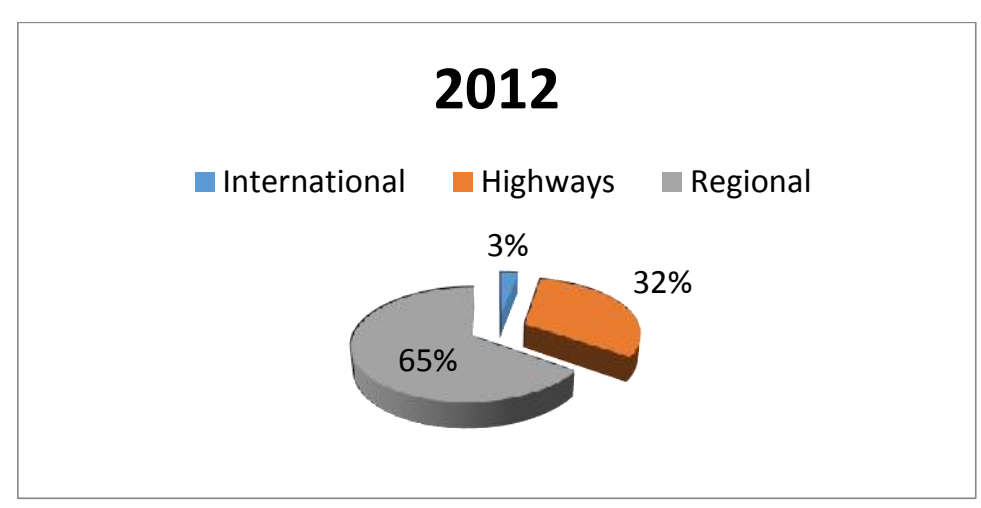

Fig.1. Kosovo roads by category

Sources: Department of Kosovo roads 
According to data presented by 2013 in the territory where we $2,005.5 \mathrm{~km}$ international road highways are $4 \% 31 \%$ while $65 \%$ are regional roads.

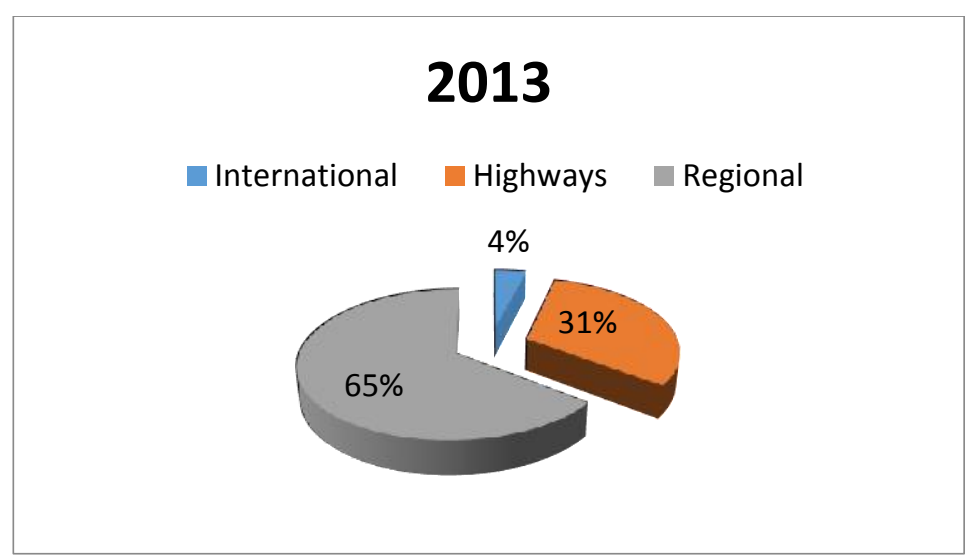

Fig .2. Kosovo roads by category

Sources: Department of Kosovo roads

The roads of Kosovo by categories in kilometers $(\mathrm{km})$ of paved roads for 2012 are $1865.4 \mathrm{~km}$ of asphalted we saw for 2012 were $120.1 \mathrm{~km}$ of paved roads while for 2013 are $120.1 \mathrm{~km}$ of roads without asphalt for 2013 are $120.1 \mathrm{~km}$.

Table. 2. Kosovo roads by categories-in kilometers $(\mathrm{km})$

\begin{tabular}{ccc}
\hline \multicolumn{4}{l}{ The roads } & of Kosovo by category \\
\hline \multicolumn{4}{c}{ - In kilometers $(\mathrm{km})$} \\
Paved & 2012 & 2013 \\
Unpaved & 1865.4 & 1885.4 \\
Total & 120.1 & 120.1 \\
\multicolumn{3}{l}{ Sources: Department of Kosovo roads }
\end{tabular}

The table above shows that in 2013 a total of $2,005.5 \mathrm{~km}$ or $1,885.5 \mathrm{~km}$ in percentage $94 \%$ are paved roads and $120.1 \mathrm{~km}$ or $6 \%$ of the roads are not paved.

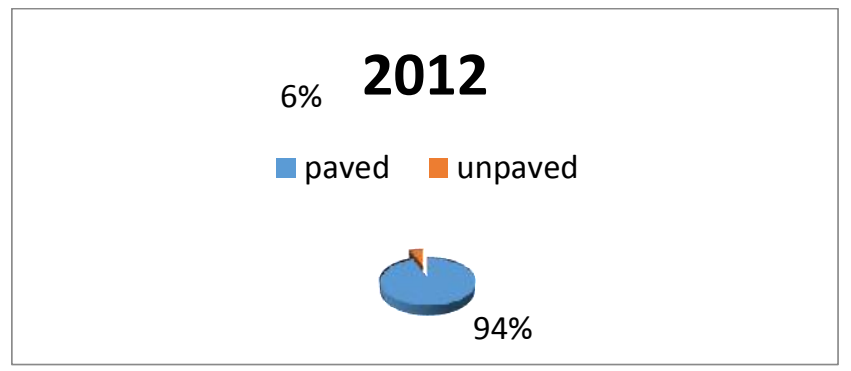

Fig. 3. Structure Kosovo roads by category

Sources: Department of Kosovo roads 
The table above shows that in 2013 a total of $2,005.5 \mathrm{~km}$ or $1,885.5 \mathrm{~km}$ in percentage $94 \%$ are paved roads and $120.1 \mathrm{~km}$ or $6 \%$ of the roads are not paved.

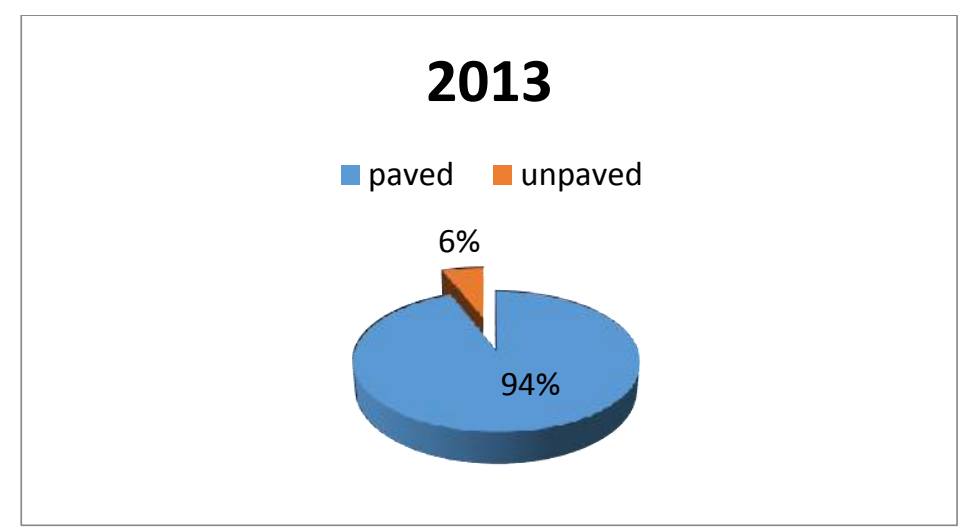

Fig. 3. Structure Kosovo roads by category

Sources: Department of Kosovo roads

\subsection{Railway Transportation}

In the territory of Kosovo have total $333 \mathrm{~km}$ rail track and 110 private transport. Circulating in Kosovo Railways diesel locomotive 8, which carry 27 wagons, 9 and 18 for passenger luggage.

Table .3. railway capacity, from Q1 2012-Q4 2013

\begin{tabular}{cccc}
\hline \multicolumn{4}{c}{ Railway capacity, from Q1 2012 to Q2 2013 } \\
\hline Period & $\begin{array}{c}\text { Number of passengers } \\
\text { in thousands }\end{array}$ & $\begin{array}{c}\text { Quantity of goods } \\
\text { carrying a thousand tons }\end{array}$ & $\begin{array}{c}\text { The amount of goods transported } \\
\text { in millions of tons - km }\end{array}$ \\
Q1-2012 & 88 & 173 & 13 \\
Q2-2012 & 96 & 152 & 7 \\
Q3-2012 & 95 & 231 & 13 \\
Q4-2012 & 88 & 269 & 16 \\
Total & 367 & 825 & 49 \\
2012 & & 221 & 8 \\
Q1-2013 & 82 & 282 & 11 \\
Q2-2013 & 96 & 171 & 12 \\
Q3-2013 & 99 & 231 & 43 \\
Q4-2013 & 92 & 905 & \\
Total & 369 & & \\
2013 & & &
\end{tabular}

Sources: Kosovo Railways.

In the fourth quarter of 2013 the number of passengers that the train as a means of travel, is about 92 thousand. In reports fourth quarter of 2012 the number of passengers has increased $29.5 \%$.

Transport of goods by rail in the fourth quarter of 2013 was 231 thousand tons, compared to the same quarter last year there was $14: 36 \%$ discount.

Number of passengers in thousands for 2012 is $50 \%$ also for 2013 is $50 \%$ 


\section{Passenger numbers in thousands}
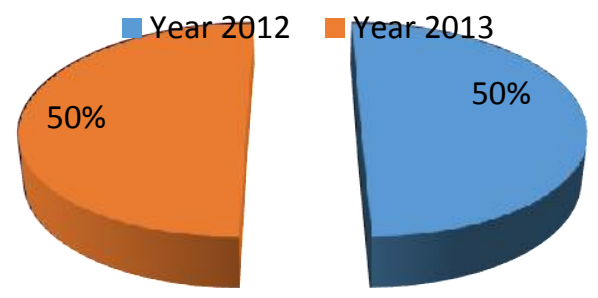

Fig .4. Number of passengers according year

Sources: Kosovo Railways.

The quantity of goods carried in thousand tons for 2012 are $49 \%$ while the amount of goods in Kosovo Railways for 2013 increased to $52 \%$ (80 quantity of goods)

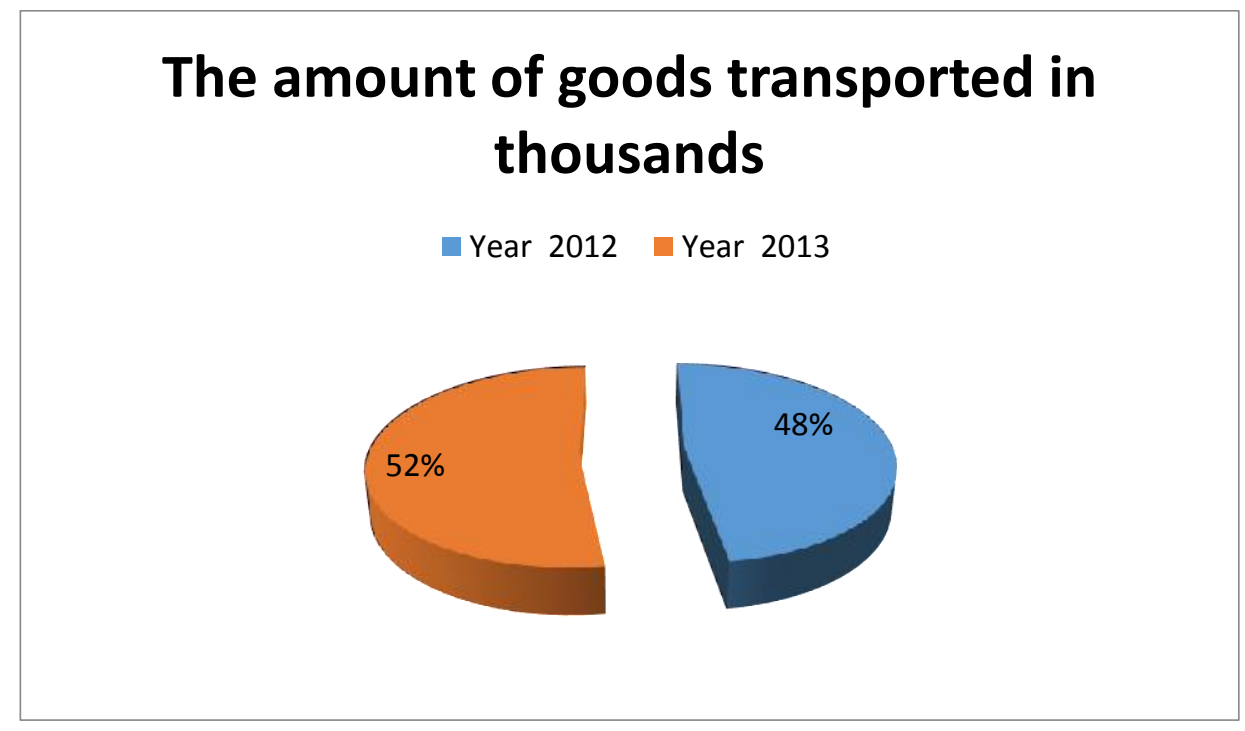

Fig .5. The amount of freight carried in tons

Sources: Kosovo Railways.

The amount of goods transported in millions of tons - $\mathrm{km}$ for 2012 is 53\% while for 2013 showed a deduction for ( 6 quantities of goods transported in million tone - $\mathrm{km}$ ) $47 \%$ 


\section{The amount of goods transported in millions of tonnes-km}

Year $2012 \quad$ Year 2013

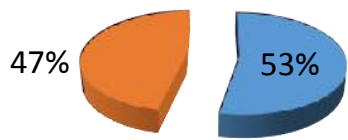

Fig. 6. Amount of freight tone-kilometers carried

Sources: Kosovo Railways.

\subsection{Air Transport}

The number of flights in the fourth quarter of 2013 was 1,452 or 13:47\% less than in the same quarter last year $(\mathrm{Q} 4,2012)$.

Table.4. the number of flights by quarter for the period Q1 2012 - Q4 2013

\begin{tabular}{cccccc}
\hline \multicolumn{7}{c}{ Number of flights according three-month period } \\
\hline \multicolumn{7}{c}{ Q1 } & Q2 & Q3 & Q4 & Total \\
Year 2012 & 1424 & 1648 & 2197 & 1678 & 6947 \\
Year 2013 & 1665 & 1809 & 2379 & 1452 & 7305 \\
\hline \multicolumn{7}{c}{ Sources: Airport Kosovo. }
\end{tabular}

Number of flights for Q1 2012 to Q4 2013, Q1 quarterly seen, Q2, Q3 has been an increase in the number of flights from 2012 to 2013 are in the last months of Q4 has a discount from 2012 to 2013. Number of flights for 2012 is 6947 and for 2013 is 7305

Fig.7. The number of flights by quarter for the period Q1-2012 Q4-2013

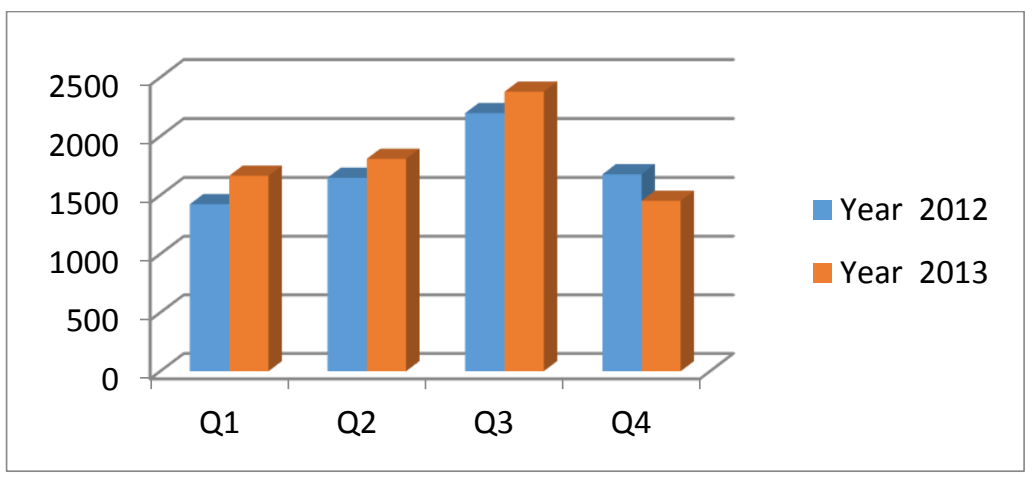

Sources: Airport Kosovo. 
Number of passengers by quarter for the period Q1 2012 - Q4 2013

Table.5. number of passengers according quarter for the period Q1 2012- Q 42013 in thousands

\begin{tabular}{cccccc}
\hline \multicolumn{6}{l}{ Number of flights according three months for the period } \\
\hline Period & Q1 & Q2 & Q3 & Q4 & Total \\
Year 2012 & 1424 & 1648 & 2197 & 1678 & 6947 \\
Year 2013 & 1665 & 1809 & 2379 & 1452 & 7305 \\
\hline
\end{tabular}

Sources: Airport Kosovo.

Number of flights for 2012 is 6947 and for 2013 is 7305

Fig.8. The number of flights for the year 2012 - 2013

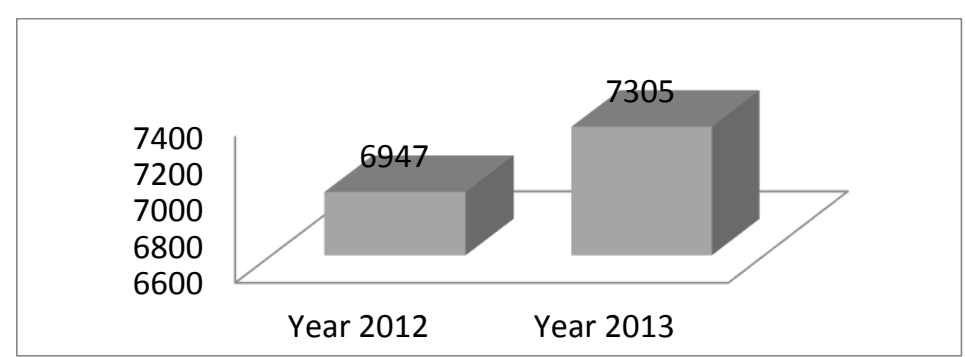

Sources: Airport Kosovo.

Number of passengers for by quarter for the period Q1 2012 to Q4 2013

Table.6. Number of passengers according four months for the year 2012 - 2013

\begin{tabular}{cccccc}
\hline \multicolumn{1}{l}{ Number of passengers according four months for the year $2012-2013$} \\
\hline Period & Q1 & Q2 & Q3 & Q4 & Total \\
Year 2012 & 293 & 366 & 530 & 339 & 1528 \\
Year 2013 & 348 & 408 & 560 & 313 & 1629 \\
\hline
\end{tabular}

Sources: Airport Kosovo

Number of passengers for 2012 is 1528 and for 2013 is 1629

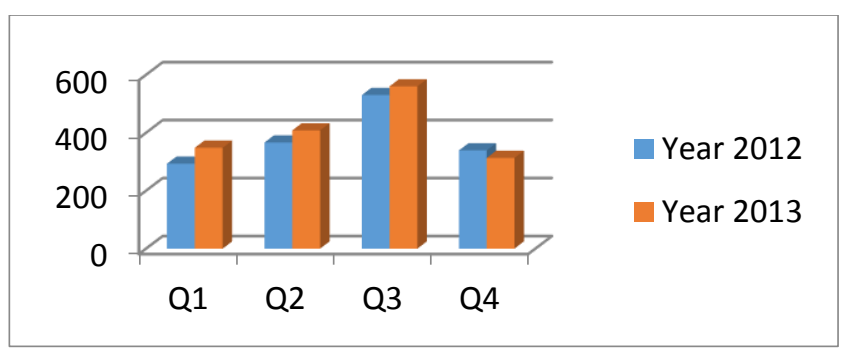

Fig.9. The number of passengers for period Q1 2012 Q4 2013

Sources: Airport Kosovo 
Table. 8. number of passengers as after months for 2012 and 2013

The average number of passengers per flight

\begin{tabular}{|c|c|c|c|c|c|c|c|c|c|c|c|c|c|}
\hline $\begin{array}{l}\text { Years / } \\
\text { Months }\end{array}$ & January & February & March & April & May & June & July & August & September & October & November & December & Total \\
\hline 2012 & 203 & 196 & 217 & 255 & 218 & 223 & 244 & 248 & 228 & 212 & 192 & 201 & 2637 \\
\hline 2013 & 201 & 210 & 217 & 223 & 223 & 230 & 232 & 245 & 225 & 220 & 207 & 219 & 2652 \\
\hline Total & 404 & 406 & 434 & 478 & 441 & 453 & 476 & 493 & 453 & 432 & 399 & 420 & 5289 \\
\hline
\end{tabular}

Sources: Airport Kosovo

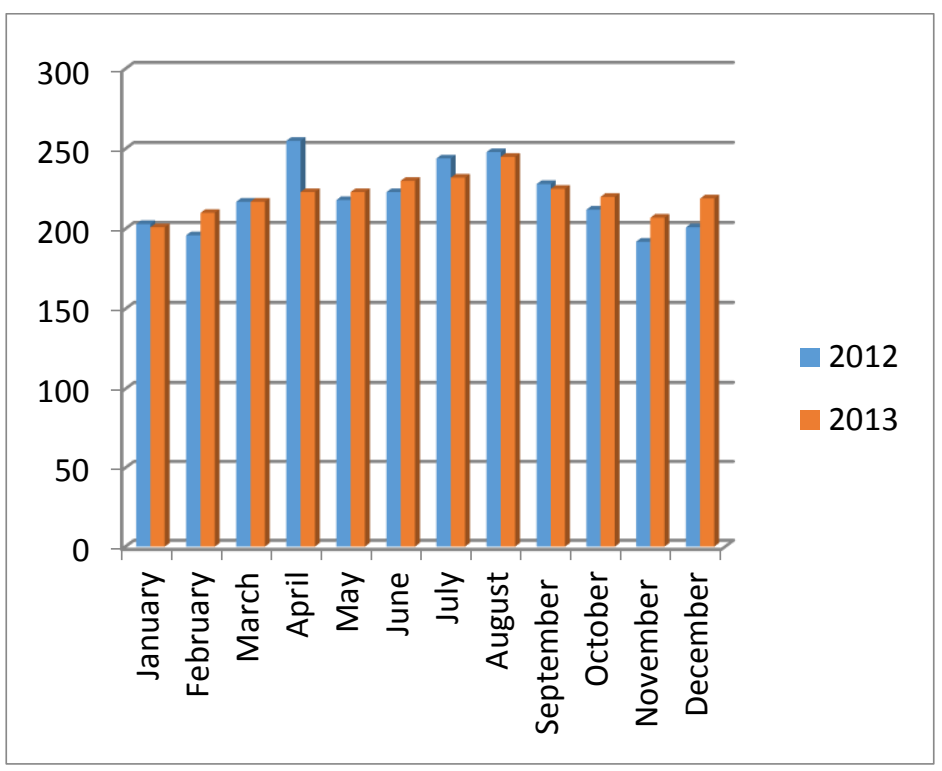

Fig. 10. number of passengers as after months for 2012 and 2013

Sources: Airport Kosovo

\section{Conclusion}

Through this research analyzed the main factors affecting transport in Kosovo and determine profit through increasing the number of passengers.

1. Increase paving roads to villages that have been gathered with easy access to cities 
2. Increasing the number of railway tracks

3. Growth of locomotives, wagons, baggage

4. Increase the number of aircraft in other city Kosovo

\section{References}

1. Brink David "Essentials of Statistics"

2. Fernandes Marcelo "Statistics for Business and Economics

3. Anthony Denis "Statistics for Health, Life and Social Sciences

4. Bohm Gerhard, Zech Günter "Introduction to Statistics and Data Analysis for Physicists"

5. Statistical Office of Kosovo 